\title{
Backyard Poultry as a Resilient Technology for Augmenting Farm Income
}

\author{
J. Hemantha Kumar*, K. Ravi Kumar, D. Srinivas, Smt P. Sri Ranjitha, \\ P. Raghu Rami Reddy, Y.G. Prasad and J.V. Prasad
}

Krishi Vigyan Kendra, Wyra, Khammam, Telangana State, India

*Corresponding author

\begin{tabular}{|c|c|}
\hline $\begin{array}{l}\text { Ke y w o r d s } \\
\text { Backyard poultry, } \\
\text { Desi, Raja Sri, } \\
\text { NICRA }\end{array}$ & $\begin{array}{l}\text { water streams and borewells. As a result of deficit rainfall, farmers are not able to get the } \\
\text { stable income and the livelihood of the farmers affected because of climatic conditions } \\
\text { prevailed in the village. Moreover, in Nacharam cluster village, farmers rear the local } \\
\text { breeds (Deshawali) which have less growth rate, less egg laying capacity and susceptible } \\
\text { to diseases. Farmers are not able to generate good income because of the poor egg }\end{array}$ \\
\hline Article Info & idea of village situation and studying the climate \\
\hline $\begin{array}{l}\text { Accepted: } \\
18 \text { January } 2019 \\
\text { Available Online: } \\
10 \text { February } 2019\end{array}$ & $\begin{array}{l}\text { resilient breed (Raja Sri) as an alternative to the desi breed for income generation to the } \\
\text { farmers and as a solution to the farmers for encouraging them towards backyard poultry } \\
\text { under NICRA. Based on Participatory Rural Appraisal (PRA) techniques, } 40 \text { farmers were } \\
\text { selected from } 5 \text { villages for Promoting back yard poultry by giving the "Raja Sri" birds. }\end{array}$ \\
\hline & $\begin{array}{l}\text { Each farmer was given } 10 \text { "Raja Sr1" birds as a unit worth of Rs. } 1000 /- \text {. The total income } \\
\text { generated from } 5 \text { villages through combined selling of eggs and meat ranged from } \\
1,40,550 / \text { - to } 1,68,940 /- \text { per annum and the total number of eggs ranged produced by } 5 \\
\text { villages ranged from } 35,520 \text { to } 40,960 \text { per annum. In Nacharam Cluster of Khammam } \\
\text { district, "Raja Sri " birds served as an alternative additional income source to the farmers } \\
\text { by selling the eggs and meat along with agriculture which improved their living standards. }\end{array}$ \\
\hline
\end{tabular}

\section{Introduction}

Rural population living in India constitutes 72.2 per cent of the total population, which is predominantly occupied by poor, marginal farmers and landless labourers. Backyard poultry production is an old age profession of rural families of India. It is the most potent source for subsidiary incomes for landless and poor farmers. It is an enterprise with low initial investment but higher economic returns and can easily be managed by women, children and old aged persons of the households. Now-a-days, poultry meat and 
eggs have been the best and cheapest sources for meeting out the per capita requirement of protein and energy for rural areas of India. It will be very difficult, to boost the egg and meat production with the desi birds in the village without the backyard poultry. India is currently producing 2.75 million tones of chicken meat and 65.48 million (2.86 million tonnes) of hen eggs/year (ICAR-DPR, 2012). Market driven backyard poultry enterprises are being recognized as a stepping stone for the poorest households enabling them to take the first step towards breaking out of the vicious circle of poverty and deprivation (Chaturvedani et al., 2015).

There is also growing evidence to demonstrate the role of rural poultry farming in enhancing the food and nutrition security of the poorest households, reducing the livelihood vulnerability, insecurity and promotion of gender equity (Ahuja and Sen, 2007). In India, the demand for local chicken and eggs is very high as compared to the broilers and layer eggs due to their better taste, texture and flavor as perceived by the local population (Sapcota et al., 2002). However, the existing traditional poultry farming is unable to meet the ever increasing demand for poultry meat and eggs due to growing population of the region. Traditionally desi varieties are used for backyard poultry production whose production potential is very low around 60-80 eggs per year, thus making the backyard poultry less economical. Therefore, to increase the productivity of backyard poultry farming, the improved varieties which are look alike indigenous chickens are now being massively introduced in the region (Singh et al., 2002). Based on studying the situation, KVK, Wyra scientists have approached the farmers with a novel idea of rearing the new breed (Raja Sri) as an alternative to the desi breed for income generation to the farmers with the following objectives;
To study the general characteristics of local desi bird and "Raja Sri" bird.

To study the no. of eggs produced by the "Raja Sri" bird.

To study the income generated by the farmers by selling of eggs and meat of "Raja Sri" bird.

\section{Materials and Methods}

A total of 2000 chicks were distributed to the 200 farmers selected based on the their interest and knowledge on back yard poultry rearing from the 5 villages (40 farmers from each village) (Table 1).

The general characteristics of local desi bird and "Raja Sri" bird were studied (Table 2). Raja Sri birds are very good in meat and egg production. The average number of eggs produced by the desi bird per annum will be around $60-80$, but by the "Raja Sri" birds, it will be around 150-160. The weight at maturity stage for egg production of desi bird is around 1.0 -1.1 kgs whereas as "Raja Sri" birds is around 1.1-1.2 kgs. They can be reared simply just like desi birds in the backyard without any difficulty. They have less in weight with good long legs and can easily escape from the predators. They are bright red in colour with medium stature similarly looks like desi birds. Just like desi birds, they eat the locally available feed, insects and other food available in the home premises and gives good delicious meat and more eggs. They have high immunity power and can easily be reared in the village conditions (Devi et al., 2012). Compared to desi birds, they will be ready in a short time for marketing and also fetches a good price in the market.

Randomly, a minimum of 2 members were selected from each village (total 10 famers from 5 villages) and the no. of eggs produced per annum, income generated by selling of eggs, no. of birds sold for meat, total income 
generated from eggs and meat of 10 farmers were studied (Table 3). Also, the no. of eggs produced per annum, income generated by selling of eggs, no. of birds sold for meat, total income generated from eggs and meat of total farmers of 5 villages were also studied (Table 4).

\section{Results and Discussion}

A unit of 10 birds $(8 \mathrm{~F}+2 \mathrm{M})$ were distributed to the each farmer. As a sample study, the income generated by 10 farmer's ( 2 farmers selected from each village) was studied. The average number of eggs produced by each bird was about 160 number of eggs. Among 10 birds, farmers majority of birds utilised for egg purpose and an average of 4-6 birds were sold by farmers for meat purpose.

The results shown that no. of eggs produced by the birds of each farmer ranged from 800 to 1440 per annum and total income levels generated by each farmer ranged from Rs.4440/- to Rs.6510/- per annum and (among 10 birds, mortality of 10-30\% observed due to predators and other reasons). The total no. of eggs produced by the birds of 10 farmers were 11,880 per annum and total income generated by the 10 farmers through combined selling of eggs (each egg Rs.4/) and meat (Rs.150/- per bird) was Rs. 51, 320/- per annum (Table 3 ).

Similarly, for the 5 villages (Each village 40
Farmers), the no. of eggs produced per annum, income generated by selling of eggs per annum, no. of birds sold for meat, total income generated from eggs and meat of farmers of 5 villages were also studied (Table 4).

The results on backyard poultry in Nacharam cluster village belonging to Khammam (D), Telangana State shown that mortality rate in birds ranged from 20-30\% which happened due to predators and other factors, the average number of eggs produced by single bird is about 160 per annum and the number of eggs produced per annum in case of 5 villages ranged from 33,600 to 40,960 and the income generated by selling of eggs (Rs.4/egg) ranged from Rs.1,34,400/- to Rs. 1,63,840/per annum. Some birds were sold for meat purpose and the income generated by selling of birds for meat in 5 villages ranged from Rs. 5100/- to Rs. 6750/-. "Raja Sri" birds served as a good income generation source for the farmers. Farmers in the 5 villages are able to generate an income ranged from Rs. $1,40,550 /-$ to Rs. $1,68,940 /-$ by combined selling of eggs and meat produced by the birds. The average income of the farmer (Each village 40 Farmers) ranged from Rs. 3513.7/- to Rs. 4223.5/-. Further, farmers with the remaining number of birds utilizing for egg and meat production there by getting a sustainable income generation for their livelihood and improving their living standards.

Table.1 No. of chicks distributed and No. of beneficiaries

\begin{tabular}{|c|c|c|c|}
\hline Villages & No. of beneficiaries & $\begin{array}{c}\text { Unit size } \\
\text { (No. of chicks) }\end{array}$ & $\begin{array}{c}\text { No. of Chicks } \\
\text { distributed }\end{array}$ \\
\hline Nacharam & 40 & 10 & 400 \\
\hline Colony Nacharam & 40 & 10 & 400 \\
\hline Gangula Nacharam & 40 & 10 & 400 \\
\hline Muniya Thanda & 40 & 10 & 400 \\
\hline Badru Thanda & 40 & 10 & 400 \\
\hline Total & $\mathbf{2 0 0}$ & $\mathbf{1 0}$ & $\mathbf{2 0 0 0}$ \\
\hline
\end{tabular}


Table.2 Comparison of the characteristics of the Local desi breed and Raja Sri breed

\begin{tabular}{|c|c|c|}
\hline Particulars & Local variety & $\begin{array}{c}\text { Resilient } \\
\text { chicks } \\
\text { (Raja Sri) }\end{array}$ \\
\hline Weight (2 months) (Gms) & $350-400$ & 500 \\
\hline Mortality rate (\%) & 90 & 98 \\
\hline Egg laying stage & 6 months & 5.5 months \\
\hline $\begin{array}{c}\text { Average number of egg } \\
\text { production/one bird } \\
\text { (per annum) }\end{array}$ & $60-80$ & $150-160$ \\
\hline $\begin{array}{c}\text { Income to the farmers by } \\
\text { selling eggs (Rs.) }\end{array}$ & $120-180$ & $\begin{array}{c}600-640 \\
\text { (Rs. }\end{array}$ \\
\hline Egg weight in (Gms) & $45-50$ & 52 \\
\hline $\begin{array}{c}\text { Kg Weight gain of the } \\
\text { bird }\end{array}$ & 5 months \\
\hline $\begin{array}{c}\text { Weight of the bird at Egg } \\
\text { laying stage (Gms) }\end{array}$ & $1000-1100$ & 4 months \\
\hline
\end{tabular}

Table.3 No. of Eggs produced, meat produced and income generated by "Raja Sri" birds of 10 beneficiaries

\begin{tabular}{|c|c|c|c|c|c|c|c|c|}
\hline S.No & $\begin{array}{c}\text { No. of } \\
\text { chicks } \\
\text { distrib } \\
\text { uted } \\
(8 \mathrm{~F}+2 \\
\text { M) }\end{array}$ & $\begin{array}{l}\text { Mortality } \\
(\%)\end{array}$ & $\begin{array}{l}\text { Existing no. } \\
\text { of chicks }\end{array}$ & $\begin{array}{c}\text { No. of eggs } \\
\text { produced } \\
\text { per annum } \\
\text { (Avg.160 } \\
\text { eggs per } \\
\text { annum) }\end{array}$ & $\begin{array}{c}\text { Income } \\
\text { generated } \\
\text { by selling of } \\
\text { eggs (Rs.4 } \\
\text { per egg) }\end{array}$ & $\begin{array}{c}\text { No. of birds } \\
\text { sold for meat } \\
\text { (Rs.150 per } \\
\text { bird) } \\
\text { (avg. } 4-6 \\
\text { birds sold }\end{array}$ & $\begin{array}{c}\text { Remaining no. of } \\
\text { birds }\end{array}$ & $\begin{array}{l}\text { Total income } \\
\text { Generated from } \\
\text { eggs and meat }\end{array}$ \\
\hline (a) & (b) & (c) & (d) & (e) & (f) & (g) & (h) & $(\mathrm{f}+\mathrm{g})$ \\
\hline 1 & 10 & 20 & $\begin{array}{c}08 \\
(6 \mathrm{~F}+2 \mathrm{M})\end{array}$ & 960 & 3840 & 750 & $\begin{array}{c}3 \\
(2 \mathrm{~F}+1 \mathrm{M})\end{array}$ & 4590 \\
\hline 2 & 10 & 10 & $\begin{array}{c}09 \\
(7 \mathrm{~F}+2 \mathrm{M})\end{array}$ & 1120 & 4480 & 900 & $\begin{array}{c}3 \\
(2 \mathrm{~F}+1 \mathrm{M})\end{array}$ & 5380 \\
\hline 3 & 10 & 10 & $\begin{array}{c}09 \\
(8 \mathrm{~F}+1 \mathrm{M})\end{array}$ & 1280 & 5120 & 900 & $\begin{array}{c}3 \\
(2 \mathrm{~F}+1 \mathrm{M})\end{array}$ & 6020 \\
\hline 4 & 10 & 10 & $\begin{array}{c}09 \\
(8 \mathrm{~F}+1 \mathrm{M})\end{array}$ & 1440 & 5760 & 750 & $\begin{array}{c}3 \\
(2 \mathrm{~F}+1 \mathrm{M})\end{array}$ & 6510 \\
\hline 5 & 10 & 20 & $\begin{array}{c}08 \\
(7 \mathrm{~F}+1 \mathrm{M})\end{array}$ & 1120 & 4480 & 750 & $\begin{array}{c}3 \\
(2 \mathrm{~F}+1 \mathrm{M})\end{array}$ & 5230 \\
\hline 6 & 10 & 30 & $\begin{array}{c}07 \\
(5 \mathrm{~F}+2 \mathrm{M})\end{array}$ & 800 & 3200 & 600 & $\begin{array}{c}4 \\
(2 \mathrm{~F}+2 \mathrm{M})\end{array}$ & 3800 \\
\hline 7 & 10 & 10 & $\begin{array}{c}09 \\
(7 \mathrm{~F}+2 \mathrm{M})\end{array}$ & 1120 & 4480 & 750 & $\begin{array}{c}3 \\
(2 \mathrm{~F}+1 \mathrm{M})\end{array}$ & 5230 \\
\hline 8 & 10 & 20 & $\begin{array}{c}08 \\
(6 \mathrm{~F}+2 \mathrm{M})\end{array}$ & 960 & 3840 & 900 & $\begin{array}{c}4 \\
(2 \mathrm{~F}+2 \mathrm{M})\end{array}$ & 4740 \\
\hline 9 & 10 & 10 & $\begin{array}{c}09 \\
(7 \mathrm{~F}+2 \mathrm{M})\end{array}$ & 1120 & 4480 & 900 & $\begin{array}{c}4 \\
(2 \mathrm{~F}+2 \mathrm{M})\end{array}$ & 5380 \\
\hline 10 & 10 & 30 & $\begin{array}{c}07 \\
(6 \mathrm{~F}+1 \mathrm{M})\end{array}$ & 960 & 3840 & 600 & $\begin{array}{c}4 \\
(2 \mathrm{~F}+2 \mathrm{M})\end{array}$ & 4440 \\
\hline Total & 100 & & & 11,880 & $43,520 /-$ & $7,800 /-$ & & $51,320 /-$ \\
\hline
\end{tabular}


Table.4 No. of Eggs produced, meat produced and income generated by "Raja Sri” birds of 5 villages

\begin{tabular}{|c|c|c|c|c|c|c|c|c|c|c|c|}
\hline \multirow[t]{2}{*}{ S.No } & \multirow[t]{2}{*}{ Village } & \multirow{2}{*}{$\begin{array}{c}\begin{array}{c}\text { No. of } \\
\text { chicks }\end{array} \\
\text { distributed } \\
\{1 \text { unit } 10 \\
\text { birds }(8 \mathrm{~F}+ \\
2 \mathrm{M})\} / 1 \\
\text { farmer }\end{array}$} & \multirow[t]{2}{*}{$\begin{array}{c}\text { Mortality } \\
(\%)\end{array}$} & \multicolumn{2}{|c|}{$\begin{array}{c}\text { Existing no. of } \\
\text { chicks } \\
\text { (Male and } \\
\text { female) }\end{array}$} & \multirow{2}{*}{$\begin{array}{c}\text { No. of } \\
\text { eggs } \\
\text { produce } \\
\text { d per } \\
\text { annum } \\
\text { (Avg.160 } \\
\text { eggs per } \\
\text { annum }\end{array}$} & \multirow{2}{*}{$\begin{array}{c}\text { Income } \\
\text { generate } \\
\text { d by } \\
\text { selling of } \\
\text { eggs } \\
\text { (Rs.4 per } \\
\text { egg) }\end{array}$} & \multirow{2}{*}{$\begin{array}{l}\text { No. of } \\
\text { birds } \\
\text { sold for } \\
\text { meat } \\
\text { (Rs.150 } \\
\text { per } \\
\text { bird) }\end{array}$} & \multirow[t]{2}{*}{$\begin{array}{l}\text { Remaining } \\
\text { no. of birds }\end{array}$} & \multirow{2}{*}{$\begin{array}{c}\text { Total } \\
\text { income } \\
\text { Generated } \\
\text { from eggs } \\
\text { and meat }\end{array}$} & \multirow[t]{2}{*}{$\begin{array}{l}\text { Avg. Income of } \\
\text { the farmer } \\
(40 \text { farmers/ } \\
\text { village })\end{array}$} \\
\hline & & & & Male & Female & & & & & & \\
\hline & (a) & (b) & (c) & \multicolumn{2}{|c|}{ (d) } & (e) & (f) & (g) & (h) & i & $(\mathrm{i} / 40)$ \\
\hline 1 & $\begin{array}{c}\text { Nacharam } \\
\text { (40 farmers/ } \\
\text { village) }\end{array}$ & 400 & 20 & 64 & 256 & 40,960 & $\begin{array}{c}1,63,840 / \\
-\end{array}$ & $\begin{array}{c}5,100 \\
(34 * 150)\end{array}$ & $\begin{array}{c}286 \\
(234 \mathrm{~F}+52 \mathrm{M})\end{array}$ & $1,68,940 /-$ & $4223.5 /-$ \\
\hline 2 & $\begin{array}{c}\text { Colony } \\
\text { Nacharam } \\
\text { (40 farmers/ } \\
\text { village) }\end{array}$ & 400 & 30 & 70 & 210 & 33,600 & $\begin{array}{c}1,34,400 / \\
-\end{array}$ & $\begin{array}{c}6150 \\
(41 * 150)\end{array}$ & $\begin{array}{c}239 \\
(191 \mathrm{~F}+48 \mathrm{M})\end{array}$ & $1,40,550 /-$ & 3513.7/- \\
\hline 3 & $\begin{array}{c}\text { Gangula } \\
\text { Nacharam } \\
\text { (40 farmers/ } \\
\text { village) }\end{array}$ & 400 & 25 & 78 & 222 & 35,520 & $\begin{array}{c}1,42,080 / \\
-\end{array}$ & $\begin{array}{c}5550 \\
(37 * 150)\end{array}$ & $\begin{array}{c}263 \\
(206 \mathrm{~F}+57 \mathrm{M})\end{array}$ & $1,47,630 /-$ & $3690.7 /-$ \\
\hline 4 & $\begin{array}{c}\text { Muniya } \\
\text { Thanda } \\
\text { (40 farmers/ } \\
\text { village) }\end{array}$ & 400 & 28 & 58 & 230 & 36,800 & $\begin{array}{c}1,47,200 / \\
-\end{array}$ & $\begin{array}{c}6750 \\
\left(45^{*} 150\right)\end{array}$ & $\begin{array}{c}243 \\
(203 \mathrm{~F}+40 \mathrm{M})\end{array}$ & $1,53,950 /-$ & $3848.7 /-$ \\
\hline 5 & $\begin{array}{c}\text { Badru } \\
\text { Thanda } \\
\text { (40 farmers/ } \\
\text { village) }\end{array}$ & 400 & 25 & 66 & 234 & 37,440 & $\begin{array}{c}1,49,760 / \\
-\end{array}$ & $\begin{array}{c}6300 \\
(42 * 150)\end{array}$ & $\begin{array}{c}258 \\
(213 \mathrm{~F}+45 \mathrm{M})\end{array}$ & $1,56,060 /-$ & $3901.5 /-$ \\
\hline & & Total & & & & $1,84,320$ & $\begin{array}{c}7,37,280 / \\
-\end{array}$ & 29,850/- & & $7,67,130 /-$ & \\
\hline
\end{tabular}


In conclusion, the backyard poultry production can be easily boost up with improved breed of poultry like "Raja Sri" birds and can promise a better production of meat and egg to the farmers for income generation and livelihood. It will serves as an dual purpose to the farmers both for protein source from egg and income generation through selling of eggs and meat. Most of the families in rural areas who are agriculture dependent can have the backyard poultry as an allied sector to the agriculture through which the living standards and. income levels improves. Backyard poultry plays an important role in poverty alleviation, nutritional security and promotion of gender equality especially in developing countries (Gueye, 2000). It ensures meat and egg availability in remote areas, acts as a biological pest control agent and caters to the needs of traditional ceremonies (Alders et al., 2003).

\section{References}

Alders R, Cambaza, A.B and Harun, M. 2003.Village chickens, food security and HIV/AIDS mitigation. Retrieved from www.kyeemafoundation.org Chaturvedani, A.K., Niranjan Lal, Khalid, Khyalia, N.K and Jitendra Pratap. 2015. Empowering Tribal Women through Backyard Poultry in Bastar District of Chhattisgarh. Journal of Krishi Vigyan. 3:19-22.

Devi, K.S., Rao, S.T.V., Preetham, V.C and Narasimha, J. 2012. Genetic study on Immunocompetence traits in certain synthetic varieties of backyard poultry birds. In: Proc. of XII ISAGB. 2012. 164-165.

Gueye E F. 2000. The role of family poultry in poverty alleviation, food security and the promotion of gender equality in rural Africa. Outlook on Agriculture. 29(2): 129-136.

ICAR-Directorate of Poultry Research. 2012. Vision 2050 . http://www.pdonpoultry.org/pdpnew/i mages/extfiles/reports/vision_2050.pd $\mathrm{f}$

Sapcota, D., Islam, R. and Sheikh, I.U. 2002. Conserving poultry biodiversity of India. Livestock International. 6 (12): 20-23.

Singh, R.V., Saxena, V.K. and Sharma, D. 2002. Technological developments in the poultry sub-sector; In technology options for sustainable livestock production in India. Proceedings of the workshop on Documentation, Adoption and Impact of Livestock Technologies in India. 99-103.

\section{How to cite this article:}

Hemantha Kumar, J., K. Ravi Kumar, D. Srinivas, Smt P. Sri Ranjitha, P. Raghu Rami Reddy, Y.G. Prasad and Prasad, J.V. 2019. Backyard Poultry as a Resilient Technology for Augmenting Farm Income. Int.J.Curr.Microbiol.App.Sci. 8(02): 2252-2257. doi: https://doi.org/10.20546/ijcmas.2019.802.261 